\title{
Impact of E-Commerce Sales on Profitability and Revenue. The Case of the Manufacturing Industry
}

\author{
Pedro Lorca, Javier de Andres, Julita Garcia-Diez \\ University of Oviedo, School of Business and Economics \\ Avda. del Cristo, s/n-33071 Oviedo. Spain \\ E-mail.plorca@uniovi.es,jdandres@uniovi.es,julita@uniovi.es \\ cross $^{\text {ref }}$ http://dx.doi.org/10.5755/j01.ee.30.5.21254
}

\begin{abstract}
E-commerce has grown significantly in recent years. Although the factors that contribute to the implementation of ecommerce have been studied in prior literature, little has been done about the impact that the introduction of e-commerce has on both profitability and revenue. This is important because, as Solow (1987) points out, the information technology expenditures do not always allow firms to achieve a better performance. For this purpose, the authors use the data from the Spanish Survey on Business Strategies (ESEE). The research covers an eight-year period (2008-2015). 2,544 Spanish companies belonging to the manufacturing sector were analysed. Results show that neither business-to-business (B2B) nor business-to-consumers (B2C) e-commerce seem to have influence on the revenue growth. Therefore, a substitution effect may exist between the sales by physical channels and e-commerce sales. However, the authors have found evidence that companies which adopt a high level of e-commerce (B2C and B2C simultaneously) immediately experience increase in their profitability. Moreover, if firms adopt only B2B or B2C the positive effects on profitability are achieved in the year subsequent to that of the measurement of the e-commerce status.
\end{abstract}

Keywords: E-commerce; Sales; Profitability; E-Business; Manufacturing firms.

\section{Introduction}

Taking advantage of new methods to improve business processes can be a key factor for the success of companies. Faced with the challenges of economic globalization and competitiveness, electronic commerce can offer many benefits to firms: reduction of costs (both information exchange, transaction and marketing costs), access to geographically dispersed markets, reduction of delivery times, closer relationship with the customer through more personalized marketing, ability to compete in more dimensions than price, and many more. Therefore, ecommerce decisions are more and more often treated not as a competitive advantage, but a necessity, which helps to avoid the lagging behind competitors (Barsauskas, Sarapovas, \& Cvilikas, 2008). Customers also benefit from transacting via e-commerce because of its easiness and convenience (see e.g., e-services in the logistics sector Dębkowska, 2017). The ability to remotely place digital orders saves both part of the time required to complete a transaction as well as the time spent searching for products. Computer-driven search engines allow buyers to search the inventories of thousands of stores in just seconds.

Moreover, information and communication technologies (ICT) play a very important role in this growth. This is because ICT have strongly changed the relationship between companies and their customers. There are two forces that have led to the strong increase in e-commerce: the great progress of technology, and the massive growth of the number of the internet users.

In Spain, retail trade has experienced an average annual growth over the last three years of $3.3 \%$ after seven years of reductions (INE, 2017). On the other hand, e-commerce has an average annual growth rate of more than $22 \%$. This growth has allowed sales through e-commerce to exceed 23,000 million of Euros in 2016 (CNMC, 2017). Ecommerce includes transactions through the Internet or other computer networks, involving the transmission of property rights or use of goods and/or services. Thus, ecommerce encompasses both goods and services. If the sales of only retail goods is considered, sales through e-commerce have grown more than $11 \%$ per year over the last three years (CNMC, 2017). However, only $20 \%$ of Spanish companies sell online (INE, 2017). Nevertheless, there is still a gap compared to other European countries, where e-commerce is more commonly used: such as Denmark (32\%), Ireland (31\%), Belgium (29\%), Norway (28\%), or the Czech Republic (24\%) (Eurostat, 2019).

Although the aggregate e-commerce sales figures have been significantly growing in recent years, the question is whether companies that implement e-commerce improve their sales and their profitability. Companies implement ecommerce with varying intensity, so a more detailed analysis must be carried out, in order to take this factor into account. For example, some firms implement only B2B (business to business) e-commerce, others only $\mathrm{B} 2 \mathrm{C}$ (business to consumers) e-commerce and others both $\mathrm{B} 2 \mathrm{~B}$ $\& \mathrm{~B} 2 \mathrm{C}$ e-commerce. We think that the true commitment with e-commerce lies in the adoption of both B2B and B2C e-commerce. Therefore, the implementation of e-commerce may have different results depending on the degree of commitment. Despite being an issue of great interest, it has been rarely studied in literature.

The present paper analyses the effect on sales growth and profitability of the implementation of e-commerce by Spanish firms belonging to the manufacturing sector between 2008 and 2015. There are theoretical reasons that explain why the adoption of e-commerce may affect sales 
and profitability. These reasons give support to the theoretical framework of this paper. To test our hypotheses, we used as data source the Business Strategy Survey (ESEE), drawn up by the Spanish SEPI Foundation (Sociedad Estatal de Participaciones Industriales) over a sufficiently long period (eight years). To reach the proposed goal we estimated a series of panel regression models taking into account both the intensity of e-commerce adoption and the lagged effect.

\section{Theoretical Framework}

E-commerce is a broad concept that includes the purchase, sale and exchange of products, services and information through computer networks (including the Internet) (Gunasekaran et al., 2002). Originally, the term was applied to transactions made by electronic means, such as electronic data interchange (EDI). However, with the arrival of the Internet in the mid-1990s, the sale of products and services through the network became widespread, using electronic payment methods such as credit cards. Since then, companies have been concerned about staying ahead and being able to offer what their customers are calling for today.

There are many ways a firm can run an e-commerce business:

- Dropshipping. A firm sells items in its website that someone else manufactures and delivers to the customers.

- Wholesaling and warehousing. A firm acquires products in bulk and store them in a warehouse.

- White-labelling. A firm manufactures a white label product which is sold under another firm's brand name.

- Manufacturing. A firm sells in its website products manufactured by itself.

- Subscription-based. A firm delivers its products or provides its services to customers at regular, scheduled intervals.

Based on the parties involved in the business transaction, three types of participants can be identified in e-commerce: companies, consumers, and public bodies (Figure 1). According to Bolumole (2001), in the case of companies, the most relevant forms of electronic commerce are:

- B2B (business to business). Business transactions between companies. B2B is a model of commercial transactions between companies using the Internet. Therefore, it involves the company's supply chain and relations with suppliers.

- B2C (business to consumers). Business transactions between companies and consumers. B2C is a model of commercial transactions between the company and private consumers using the Internet rather than a physical store. This is the deepest e-commerce market.

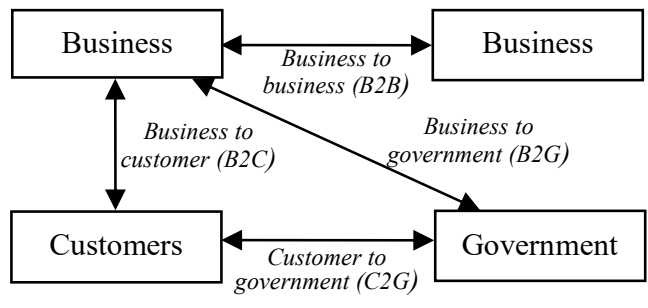

Figure 1. E-Commerce Models Source: Kvainauskaite, Sarapovas, \& Cvilikas (2005)
When a company has the ability to receive orders online, it can be considered that it carries out e-commerce. This means that both the $\mathrm{B} 2 \mathrm{~B}$ and $\mathrm{B} 2 \mathrm{C}$ realms are taken into account (Falk \& Hagsten, 2015). However, companies do not implement e-commerce with the same intensity. For example, some firms implement only B2B e-commerce, others only B2C and others both options. Coviello \& Brodie (2001) claim that the differences between B2B and B2C ecommerce are not significant and do not deserve specific attention when developing marketing concepts. So, the B2B versus $\mathrm{B} 2 \mathrm{C}$ divide is a simplistic and obsolete concept (Dant \& Brown, 2008). Consequently, Iankova et al. (2018) propose mixed models to refer to businesses that sell products to both other business and individual consumers (for example, Amazon has many business customers and partners, as well as its $\mathrm{B} 2 \mathrm{C}$ retail). Distinction between business-to-consumer (B2C) and business-to-business (B2B) relationships also causes problems from the point of view of consumer protection (Namysłowska, 2013). As a result, we consider that there are companies that only implement B2B or B2C e-commerce to send the markets a signal of their commitment with emerging technologies. However, this is a partial view of e-commerce that prevents exploiting all its advantages. Therefore, the true commitment with e-commerce lies in the adoption of both B2B and B2C options (Figure 2).

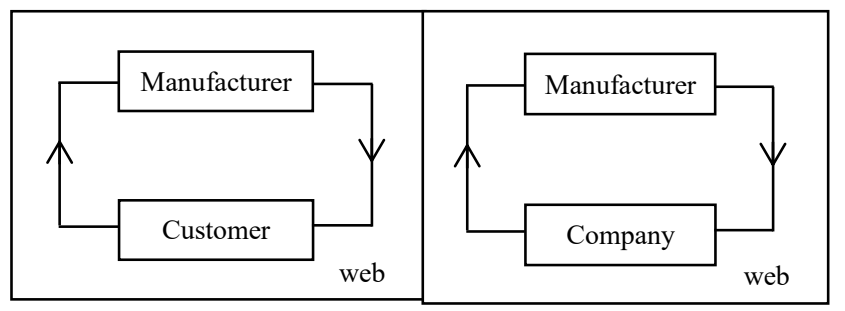

Figure 2. True Commitment with R-Commerce

The progress of $\mathrm{B} 2 \mathrm{C}$ e-commerce is closely linked to the growth of online shoppers. This is because e-commerce provides multiple advantages for both firms and consumers. E-firms are able to transact with buyers at a lower cost, while providing customers with increased product selection and information along various dimensions (Willis, 2004).

For companies, e-commerce provides an additional channel for the promotion and distribution of their products. The growing importance of B2B and B2C communication and the relationship with the customers are influenced by dynamic changes in the e-marketplace (Davidaviciene, Pabedinskaite, \& Davidavicius., 2017). Hence, e-commerce has been adopted as a means to reduce operating costs and as a way to increase revenues (Gunasekaran, Marri, McGaughey, \& Nebhwani, 2002). Moreover, companies can use digital technologies to increase the differentiation of products, thereby reducing price competition. In the case of manufacturing firms, e-commerce offers a unique opportunity to establish a direct relationship with customers on a global scale (Jelassi \& Leenen, 2003).

E-commerce allows consumers to compare a large number of goods and services from different vendors (Jan, 2012). Contents with informational quality are necessary for online shopping decisions (Ziaullah, Yi, Akhter, \& Khan, 2014). In addition, consumers can buy without worrying about opening hours and with just one click from their 
home. Moreover, it offers new ways to more accurately measure customer preferences (Michal, 2012; Svatosova, 2013). Therefore, e-commerce offers opportunities for personalized marketing, targeted advertising, price discrimination, and customized products. Finally, emarketplaces help companies to provide relevant information about their products to potential buyers in an efficient way. Thus, there are many reasons why ecommerce can positively affect social welfare, although the question of who benefits more remains controversial (Bakos, 2001).

\section{E-Commerce and Revenue}

Given the growth of e-commerce in recent years, the question is whether companies increase their turnover. As pointed out by Duch-Brown, Grzybowski, Romahn, \& Verboven (2017), although the introduction of the online channel has not led to lower prices in general, there is a considerable positive effect on total sales because a significant fraction of consumers considers the online channel to be more convenient. The online distribution channel thus swipes away some traditional sales, but it also activates consumers who find the online channel more appealing. Similarly, Jelassi, \& Leenen (2003) consider that the adoption of e-commerce should be reflected in an increase in sales. One reason to invest in online distribution is to extend the customer-base in order to sell more. In this way, online distribution becomes a means to grow by attracting new customer groups, e.g., young people starting their careers (Bergendahl, 2005). Cao \& Li (2015) identify five mechanisms by which cross-channel integration affects firm sales growth: improved trust, increased customer loyalty, higher consumer conversion rates, greater opportunities to cross-sell, and the loss of special channel features.

However, there are cases where substantial online revenues will be associated with equally large reduction in offline revenues. This is what Bergendhal (2005) calls "cannibalization". In relation to this, Duch-Brown, Grzybowski, Romahn, \& Verboven (2017) argue that there is considerable substitution between the online and traditional channels.

Finally, sales through e-commerce, despite the importance of their absolute amount, represent only a very small percentage of the total sales of the manufacturing companies. Therefore, the increase in total sales caused by the adoption of e-commerce might be imperceptible. It may also happen that, even though companies implement B2C ecommerce, they are not taking full advantage of its potential as the motivation for the implementation is only to send a signal to the markets without a real committment. In fact, in France more than $50 \%$ of the companies that implemented B2C did not increase their sales (INSEE, 2014).

Therefore, assessing whether the implementation of ecommerce finally translates into an increase in sales is an interesting question. We hypothesize that:

H1. The adoption of e-commerce by manufacturing firms has no effect on their revenue.

\section{E-Commerce and Profitability}

Today, more and more companies become interested in e-commerce as one of the instruments for business efficiency improvement (Barsauskas, Sarapovas, \& Cvilikas, 2008). This is because electronic transactions are carried out at a lower cost than personal, telephone or mail transactions.

Bergendahl (2005) identifies several "cost savings from online operations" in the field of operating cost for sales, for distribution, for holding inventory, and for ordering and payment. After reviewing the literature, it is possible to find several opportunities for cost savings using e-commerce:

- In most cases e-commerce is treated as a better technological tool for the realisation of recurrent processes, which helps to reduce some cost positions or to avoid them at all (Barsauskas, Sarapovas, \& Cvilikas, 2008).

- If the company operates only through electronic commerce, it can take advantage of places with lower costs, both labor and real estate.

- Logistics become more efficient as products are directly shipped from a manufacturer or wholesaler to an end-user (Reijinders, \& Hoohgeveen, 2001).

- E-firms, as opposed to traditional companies, can operate with a smaller number of warehouses, since e-firms do not need physical proximity to the customer.

- The lack of face-to-face interaction with customers reduces the need for a large workforce of salespeople (Willis, 2004).

- E-commerce allows cost savings since it contributes to an improvement in supply chain management. E-firms can reduce the amount of inventories minimizing the risk of stock out. So, these firms are able to reduce warehousing costs.

- Advertising expenses can be reduced in the case of e-firms. This is because these firms use electronic platforms to market their products. The use of e-infrastructures as cost-efficient platforms allows companies to reach more potential customers at a lower cost.

- Electronic commerce increases the product portfolio. In addition, companies can offer very detailed information about the characteristics of the goods or services. E-firms can cheaply provide wide descriptions of goods and services, visual displays of products including foreground views, and information about complementary products (Bergendahl, 2005). With increased product diversity, efirms have the option of operating more like department stores (Willis, 2004).

To sum up, e-firms extensively use ICT, so it is possible to decrease transaction costs, the level of stocks held, and advertising, marketing and logistic costs. These cost savings are achieved in part through a reduction in the amount of labour required for each business task (Willis, 2004). As one of the most direct effects of cost reductions is an increase in profitability, we propose Hypothesis 2 as follows:

$\mathrm{H} 2$. The adoption of e-commerce by manufacturing companies improves their profitability.

\section{Control Variables}

The review of the previous literature shows that there are some variables with an impact on profitability and sales growth. These variables should be taken into account when 
analysing whether the adoption of e-commerce can affect total sales and profitability. E-commerce implementation can be considered a process of adoption of a particular type of ICT. These are complex organizational processes in which the company gradually learns to use and exploit the technology, making efforts to develop the particular organizational competencies required, which leads to a greater maturity in the use of ICTs.

Since both the firm profitability and revenue growth can be influenced by other organizational factors, so we controlled for the following: firm size, company age, internationalization, customer concentration, capacity utilization, and industry. These variables are discussed in more detail below.

Traditionally, it is considered that company size involves a number of characteristics that may influence the economic performance of the company (Baumol, 1967). It is possible to argue that big firms benefit from economies of scale associated with higher production volumes, so larger companies can produce far more efficiently than small ones. Moreover, the largest companies have a greater volume of resources, so they can take advantage to work in activities that require high capital rates. This situation provides them the opportunity to work in more profitable fields with little competition (Dogan, 2013). Many papers have found a positive relationship between size and profitability (Hall \& Weiss, 1967; Ozgulbas, Koyuncugil, \& Yilmaz, 2006; Lee, 2009, among others). Nevertheless, other authors found that small firms are more profitable (Goddard, Tavakoli, \& Wilson, 2005; Voulgaris \& Lemonakis, 2014, among others). Regarding the effect of the company size on firm sales, Beck, Demirguc-Kunt, \& Maksimovic (2005) provide evidence confirming that small and medium-sized firms face greater financial, legal, and corruption obstacles compared to large firms, and that the constraining impact of obstacles on change in firm sales is inversely related to firm size.

The age of the company is also a factor that may have an influence on profitability. Over time, organizations improve learning processes. This generates effective planning and successful growth strategies. Therefore, older firms have experience advantages, which enable them to achieve superior sales growth (Autio, Sapienza, \& Almeida, 2000). However, other authors (Steffens, Davidsson, \& Fitzsimmons, 2009) argue that young firms are more innovative and more responsive to environmental changes and market opportunities than older firms, which enables them to capitalize on discovery advantages and grow sales. It should also be taken into account that innovation investment activities carried out by younger firms are riskier than those of older firms (Coad, Segarra, \& Teruel, 2016). Over time, companies acquire more experience and more resources, which allows them to increase their knowledge and to reduce uncertainty (Levitt \& March, 1988; Lorca, De Andres, \& Garcia-Diez, 2017). Moreover, older firms enhance their reputation and position in the market (Coad, Segarra, \& Teruel, 2016). Therefore, there is evidence of the direct effect of firm age on the improvement of the organizational performance (Argote, 1999), on innovative outcomes (Tripsas \& Gavetti, 2000), and on profitability (Notta, Vlachvei, \& Samathrakis, 2010). Moreover, firm age could affect sales growth because older firms might have experience advantages enabling them to sustain international growth (Autio, Sapienza, \& Almeida, 2000).

The firm's degree of internationalization can also influence both the growth of sales and profitability. Firms operating in foreign markets are more interested in finding new opportunities, which may have a positive impact in their profitability levels. Nevertheless, the empirical findings are quite confusing and even contradictory. Researchers have found positive, negative, U-shaped, inverted U-shaped, S-shaped, and inverted S-shaped relationships between the degree of internationalization and performance (Hosseini, Brege, \& Nord, 2018). In addition, many authors (Lu \& Beamish, 2006; Filatotchev \& Piesse, 2009 ) found that exporting activity has a positive impact on sales growth.

Apart from these three control variables, we must underline that prior studies document a positive association between customer concentration and accounting rates of return (i.e., Patatoukas, 2012). Furthermore, capacity utilization may also have an impact on sales and profitability. In this regard, it is remarkable that some studies (i.e., Zhang, Sikveland, \& Hermansen, 2018) confirm a positive relationship between a reduced capacity and profitability for specific sectors of activity.

Finally, the industry in which the company operates could have a significant impact on firm profitability and sales growth, as the sector of activity determines key issues of the business environment, such as the number of competitors, dynamism or uncertainty. This has been evidence by prior studies (i.e., Sarapovas \& Cvilikas, 2006; Teo \& Bhattacherjee, 2014; Braojos, Benitez, \& Llorens, 2015, among others).

Therefore, we included in our models a number of dummy variables representing sectoral ascription.

\section{Empirical Study}

To test the formulated hypotheses an empirical study was carried out. The scope of the analysis includes Spanish companies in the manufacturing industry. This section exposes the formation of the database, the variables for the analysis, and the empirical methods used.

\section{Database}

The source of data to carry out the empirical study is the Survey on Business Strategies, prepared by the Official Department of Science and Technology of Spain. This database provides detailed information about the business strategies of manufacturing companies with ten or more employees.

The temporal scope of the study covers the period 20082015. Companies with missing data were discarded. Finally, a database containing data from 2,543 companies was compiled. Tables 1 and 2 display, respectively, sample breakdown by year and sector of activity. 
Sample Breakdown by Year

Table 1

\begin{tabular}{lcc}
\hline Year & N. of observations & Percentage \\
\hline 2008 & 1,831 & 13.65 \\
2009 & 1,782 & 13.28 \\
2010 & 1,803 & 13.44 \\
2011 & 1,807 & 13.47 \\
2012 & 1,603 & 11.95 \\
2013 & 1,671 & 12.46 \\
2014 & 1,517 & 11.31 \\
2015 & 1,402 & 10.45 \\
\hline Total & $\mathbf{1 3 , 4 1 6}$ & $\mathbf{1 0 0 . 0 0}$ \\
\hline
\end{tabular}

Sample Breakdown by Sector of Activity

Table 2

\begin{tabular}{|c|c|c|c|}
\hline Code & Sector & N. Obs. & Percentage \\
\hline sec1 & Meat & 513 & 3.82 \\
\hline $\sec 2$ & Food and Tobacco & 1,477 & 11.01 \\
\hline $\sec 3$ & Beverages & 302 & 2.25 \\
\hline $\sec 4$ & Textiles and Clothing & 846 & 6.30 \\
\hline $\sec 5$ & Leather and Footwear & 376 & 2.80 \\
\hline $\sec 6$ & Timber & 475 & 3.54 \\
\hline $\sec 7$ & Paper & 559 & 4.17 \\
\hline $\sec 8$ & Graphic Arts & 526 & 3.92 \\
\hline $\sec 9$ & Chemical and Pharmaceutical Products & 944 & 7.04 \\
\hline $\sec 10$ & Rubber and Plastic & 729 & 5.43 \\
\hline $\sec 11$ & Non-Metallic Mineral Products & 962 & 7.17 \\
\hline $\sec 12$ & Ferrous and Non-Ferrous Metals & 447 & 3.33 \\
\hline $\sec 13$ & Metal Products & 1,730 & 12.90 \\
\hline sec14 & Agricultural and Industrial Machinery & 799 & 5.96 \\
\hline $\sec 15$ & Computer, Electronic and Optical Products & 232 & 1.73 \\
\hline $\sec 16$ & Electrical Machinery and Equipment & 549 & 4.09 \\
\hline $\sec 17$ & Motor vehicles & 681 & 5.08 \\
\hline $\sec 18$ & Other Transport Equipment & 283 & 2.11 \\
\hline sec19 & Furniture & 639 & 4.76 \\
\hline \multirow[t]{2}{*}{$\sec 20$} & Other Manufacturing & 347 & 2.59 \\
\hline & TOTAL & 13,416 & $\mathbf{1 0 0 . 0 0}$ \\
\hline
\end{tabular}

\section{Variables in the Analysis}

The variables used to test the formulated hypotheses are shown in table 3 . These variables were selected taking into account the review of the literature carried out in the theoretical framework.

\section{Variables in the Analysis}

Table 3

\begin{tabular}{ll}
\hline Variable & Meaning \\
\hline $\begin{array}{l}\text { VarRevenue } \\
\text { Profitability }\end{array}$ & $\begin{array}{l}\text { Percentage change in the net sales of the company, with respect to the prior year } \\
\text { As profitability indicator, the operating profit margin ratio has been used. Margin was defined as the sum of } \\
\text { sales, changes in inventories and other current operating income less purchases, external services and personnel } \\
\text { costs. Operating income is total sales plus the change in stocks and other current operating income. } \\
\text { Business-to-business e-commerce. Dummy variable that equals } 1 \text { if the company sells online only to other } \\
\text { companies and } 0 \text { otherwise. }\end{array}$ \\
B2B & $\begin{array}{l}\text { Business-to-client e-commerce. Dummy variable that equals } 1 \text { if the company sells online only to individual } \\
\text { customers and } 0 \text { otherwise. }\end{array}$ \\
B2C & $\begin{array}{l}\text { Business-to-business and business to client e-commerce. Dummy variable that equals } 1 \text { if the company sells } \\
\text { online to both companies and individual customers and } 0 \text { otherwise. }\end{array}$ \\
B2B\&B2C & $\begin{array}{l}\text { Company age, measured in years. } \\
\text { Natural logarithm of the net sales of the company. }\end{array}$ \\
Age & Clients concentration. Proportion of total sales that corresponds to the three bigger customers. \\
LogRevenue & Percentage of utilization of the maximum production capacity of the company. \\
ClConc & Percent of exports over total sales. \\
Ucapac & Dummy variable that equals 1 if the company belongs to the i industry and 0 otherwise. \\
Exports &
\end{tabular}

VarRvenue and Profitability are the dependent variables of the models we use for testing hypotheses 1 and 2, respectively. As Kramolis \& Kotaskova (2018) point out, some companies operate in both fields (B2B and B2C ecommerce), whereas a certain number of companies operates in one field only (further referred to as "pure B2B" or "pure $\mathrm{B} 2 \mathrm{C}$ "). So, B2B, B2C and B2B\&B2C are the e-commerce indicators included in the regression equations as independent variables.

In this regard, we must take into account that it may take some time for the benefits of the implementation of B2B/B2C e-commerce on both sales and profitability to be relevant. This is because implementing B2B e-commerce is time consuming, and the long-term impact on an organization may 
be unclear for some time (Kramolis \& Kotaskova, 2018). Therefore, as an attempt to capture such an effect, we developed two models for each of the dependent variables we considered. One to study the effects in the sales or profitability of the same year the $\mathrm{B} 2 \mathrm{~B} / \mathrm{B} 2 \mathrm{C}$ status is measured (unlagged model) and another one to study the effects in the sales/profitability of the following year (lagged model).

Finally, the rest of the variables are included in the regression model as control variables. Their measurement corresponds to the year the $\mathrm{B} 2 \mathrm{~B} / \mathrm{B} 2 \mathrm{C}$ status is considered.

\section{Empirical Methods}

Our data constitutes an unbalanced panel, so we first estimated a series of panel regression models, which, for the case of $\mathrm{H} 1$ take the following form:

VarRevenue $=\boldsymbol{c}_{\mathbf{1}}$ Ecom $+c_{2}$ Age $+c_{3}$ Revenue $+c_{4}$ ClConc + $+c_{5}$ UCapac $+c_{6}$ Exports $+\sum_{j} c_{j}$ sec. dummy $y_{j}$

In addition, for $\mathrm{H} 2$ the equations are:

Profitability $=\boldsymbol{c}_{\mathbf{1}}$ Ecom $+c_{2}$ Age $+c_{3}$ Revenue $+c_{4}$ ClConc $+c_{5}$ UCapac $+c_{6}$ Exports $+\sum_{j} c_{j}$ sec. dummy $y_{j}$

In these models, Ecom can be either one of the three ecommerce indicators that were exposed in section 3.1. So, for each of the two hypotheses we estimated three regression equations. With regard to the sector dummies, and in order to avoid perfect collinearity, we excluded sector 13 (that with more observations).

Furthermore, as indicated before, we repeated all the estimations (six additional models) measuring the dependent variables in lagged form, that is, in the year subsequent to the year the independent variables were measured. This allows to correct the biases caused by a possible delay in the effects of the implementation of e-commerce and by the implementations that took place in the last months of the year. For these six additional models, the sample size is not the same as we cannot use the data corresponding to the first year of the considered period but we gain an additional year at the end of the time span of the study.

In all twelve cases, Lagrange multiplier tests evidenced that panel variance is not significant, so we estimated instead Ordinary Least Squares (OLS) models with clustered robust standard errors to compute the significance of the coefficients. In addition, we tested for the existence of influential observations through the calculation of Cook's d statistic. For the specific case of the six models used for the assessment of $\mathrm{H} 1$ (three lagged and three unlagged regressions) there was one influential observation. We deleted it from the database and repeated the analyses. Finally, we tested for multicollinearity in the sets of independent variables through the calculation of Variance Inflation Factors (VIF). The obtained results evidence that multicollinearity is not a problem as in all cases values were well below the usual thresholds.

\section{Results}

\section{Descriptive Statistics}

First, we computed some descriptive statistics about the variables in the regression equations. The results are displayed in tables 4 and 5.

Table 4

Descriptive Statistics for the Continuous Variables

\begin{tabular}{|c|c|c|c|c|c|}
\hline Variable & Mean & Std. Dev. & Q1 & Median & Q3 \\
\hline VarRevenue & -0.192 & 84.665 & -14.721 & -1.832525 & 9.071 \\
\hline Profitability & 5.132 & 65.362 & 1.2 & 6.2 & 12.4 \\
\hline Age & 31.466 & 31.198 & 18 & 26 & 39 \\
\hline Revenue & $6.96 \mathrm{e}+07$ & $3.27 \mathrm{e}+08$ & $1,666,957$ & $7,134,250$ & $3.49 \mathrm{e}+07$ \\
\hline ClConc & 46.221 & 28.763 & 22 & 40 & 70 \\
\hline UCapac & 73.636 & 18.784 & 60 & 75 & 89 \\
\hline Exports & 23.580 & 29.505 & 0 & 8.165 & 42.582 \\
\hline Variable & Mean & Std. Dev. & Q1 & Median & Q3 \\
\hline
\end{tabular}

Table 5

Frequency Tables for the e-Commerce Indicators

\begin{tabular}{lcc}
\hline E-commerce & Yes (=1) & No (=0) \\
\hline B2B & $1,289(9.61 \%)$ & $12,129(90.39 \%)$ \\
B2C & $1,076(8.02 \%)$ & $12,342(91.98 \%)$ \\
B2B\&B2C & $621(4.63 \%)$ & $12,797(95.37 \%)$ \\
\hline
\end{tabular}

It can be seen that revenues decreases and low profitability levels prevail in the sample. Most companies are somewhat old and the dispersion with regard to size measured through revenues is very high. In addition, a significant percentage of the companies mainly sell to a few number of clients. The number of firms which have unused production capacity is also relevant. Finally, a relevant part of the sample comprises companies which are only focused in the national market. With regard to the e-commerce indicators, results show that $\mathrm{B} 2 \mathrm{~B}$ and B2C e-commerce implementations have similar percentages. These findings are in line with those of Lilien (2016).

\section{Hypotheses Assessment}

Tables 6 and 7 display the regression results for the six models (three lagged and three unlagged) which we estimated to test whether $\mathrm{H} 1$ holds.

Table 6

Regression Results for the Test of H1 (Unlagged Regression)

\begin{tabular}{|c|c|c|c|c|c|c|}
\hline \multirow{2}{*}{$\begin{array}{l}\text { Dep variable= } \\
\text { VarRevenue }\end{array}$} & \multicolumn{2}{|c|}{ Ecom $=B 2 B$} & \multicolumn{2}{|c|}{ Ecom $=B 2 C$} & \multicolumn{2}{|c|}{ Ecom $=B 2 B \& B 2 C$} \\
\hline & Coef. (std. err.) & t (p-val.) & Coef. (std. err.) & t (p-val.) & Coef. (std. err.) & t (p-val.) \\
\hline Ecom & $-1.706(1.568)$ & $-1.09(0.277)$ & $-0.222(1.284)$ & $-0.17(0.862)$ & $-1.275(1.062)$ & $-1.20(0.230)$ \\
\hline Age & $-0.011(0.022)$ & $-0.49(0.624)$ & $-0.011(0.022)$ & $-0.51(0.609)$ & $-0.011(0.022)$ & $-0.51(0.612)$ \\
\hline LogRevenue & $1.842(0.229)$ & $8.02(0.000)$ & $1.810(0.226)$ & $7.99(0.000)$ & $1.818(0.227)$ & $7.99(0.000)$ \\
\hline
\end{tabular}




\begin{tabular}{|c|c|c|c|c|c|c|}
\hline $\begin{array}{l}\text { Dep variable= } \\
\text { VarRevenue }\end{array}$ & Ecom $=$ B2B & Ecom $=B 2 C$ & Ecom $=B 2 B \& B 2 C$ & $\begin{array}{l}\text { Dep variable= } \\
\text { VarRevenue }\end{array}$ & Ecom $=B 2 B$ & Ecom=B2C \\
\hline & Coef. (std. err.) & t (p-val.) & Coef. (std. err.) & & Coef. (std. err.) & t (p-val.) \\
\hline ClConc & $0.043(0.010)$ & $4.25(0.000)$ & $0.044(0.010)$ & $4.31(0.000)$ & $0.044(0.010)$ & $4.25(0.000)$ \\
\hline UCapac & $0.292(0.018)$ & $15.57(0.000)$ & $0.293(0.018)$ & $15.64(0.000)$ & $0.293(0.018)$ & $15.64(0.000)$ \\
\hline Exports & $0.037(0.017)$ & $2.15(0.032)$ & $0.037(0.017)$ & $2.16(0.031)$ & $0.037(0.017)$ & $2.17(0.030)$ \\
\hline Sec01 & $3.429(1.422)$ & $2.41(0.016)$ & $3.503(1.420)$ & $2.47(0.014)$ & $3.453(1.428)$ & $2.42(0.016)$ \\
\hline $\mathrm{Sec} 02$ & $3.874(1.042)$ & $3.72(0.000)$ & $3.890(1.041)$ & $3.74(0.000)$ & $3.888(1.041)$ & $3.73(0.000)$ \\
\hline $\mathrm{Sec} 03$ & $8.082(3.857)$ & $2.10(0.036)$ & $8.162(3.916)$ & $2.08(0.037)$ & $8.234(3.859)$ & $2.13(0.033)$ \\
\hline $\mathrm{Sec} 04$ & $2.353(1.190)$ & $1.98(0.048)$ & $2.365(1.192)$ & $1.98(0.047)$ & $2.382(1.187)$ & $2.01(0.045)$ \\
\hline $\operatorname{Sec} 05$ & $6.542(1.832)$ & $3.57(0.000)$ & $6.585(1.835)$ & $3.59(0.000)$ & $6.559(1.831)$ & $3.58(0.000)$ \\
\hline $\operatorname{Sec} 06$ & $0.206(1.472)$ & $0.14(0.888)$ & $0.259(1.471)$ & $0.18(0.860)$ & $0.269(1.473)$ & $0.18(0.855)$ \\
\hline $\operatorname{Sec} 07$ & $3.053(1.446)$ & $2.11(0.035)$ & $3.048(1.456)$ & $2.09(0.036)$ & $3.081(1.457)$ & $2.11(0.035)$ \\
\hline $\operatorname{Sec} 08$ & $0.493(1.140)$ & $0.43(0.666)$ & $0.527(1.141)$ & $0.46(0.644)$ & $0.541(1.139)$ & $0.48(0.635)$ \\
\hline $\operatorname{Sec} 09$ & $3.368(1.281)$ & $2.63(0.009)$ & $3.393(1.276)$ & $2.66(0.008)$ & $3.379(1.276)$ & $2.65(0.008)$ \\
\hline Sec 10 & $2.540(1.218)$ & $2.08(0.037)$ & $2.559(1.220)$ & $2.10(0.036)$ & $2.553(1.221)$ & $2.09(0.037)$ \\
\hline Sec11 & $-2.191(1.284)$ & $-1.71(0.088)$ & $-2.162(1.286)$ & $-1.68(0.093)$ & $-2.188(1.287)$ & $-1.70(0.089)$ \\
\hline Sec12 & $0.329(1.687)$ & $0.20(0.845)$ & $0.392(1.684)$ & $0.23(0.816)$ & $0.365(1.684)$ & $0.22(0.828)$ \\
\hline Sec14 & $2.936(1.871)$ & $1.57(0.117)$ & $2.960(1.871)$ & $1.58(0.114)$ & $3.011(1.877)$ & $1.60(0.109)$ \\
\hline Sec 15 & $0.443(2.250)$ & $0.20(0.844)$ & $0.481(2.244)$ & $0.21(0.830)$ & $0.509(2.244)$ & $0.23(0.821)$ \\
\hline Sec16 & $0.157(1.925)$ & $0.08(0.935)$ & $0.134(1.926)$ & $0.07(0.944)$ & $0.209(1.929)$ & $0.11(0.914)$ \\
\hline Sec17 & $-2.457(1.536)$ & $-1.60(0.110)$ & $-2.426(1.536)$ & $-1.58(0.114)$ & $-2.435(1.538)$ & $-1.58(0.114)$ \\
\hline Sec 18 & $12.935(6.547)$ & $1.98(0.048)$ & $12.975(6.552)$ & $1.98(0.048)$ & $12.953(6.555)$ & $1.98(0.048)$ \\
\hline Sec19 & $0.933(1.488)$ & $0.63(0.530)$ & $0.824(1.477)$ & $0.56(0.577)$ & $0.830(1.482)$ & $0.56(0.575)$ \\
\hline $\operatorname{Sec} 20$ & $2.265(1.566)$ & $1.45(0.148)$ & $2.178(1.563)$ & $1.39(0.164)$ & $2.162(1.560)$ & $1.39(0.166)$ \\
\hline Intercept & $-56.054(3.263)$ & $-17.18(0.000)$ & $-55.746(3.232)$ & $-17.25(0.000)$ & $-55.797(3.238)$ & $-17.23(0.000)$ \\
\hline $\mathrm{F}$ & \multicolumn{2}{|c|}{$28.16(\mathrm{p}<0.001)$} & \multicolumn{2}{|c|}{$28.38(\mathrm{p}<0.001)$} & \multicolumn{2}{|c|}{$28.19(\mathrm{p}<0.001)$} \\
\hline R-squared & \multicolumn{2}{|c|}{0.0547} & \multicolumn{2}{|c|}{0.0546} & \multicolumn{2}{|c|}{0.0547} \\
\hline Clusters & \multicolumn{2}{|c|}{2543} & \multicolumn{2}{|c|}{2543} & \multicolumn{2}{|c|}{2543} \\
\hline $\mathrm{N}$ & \multicolumn{2}{|c|}{13415} & \multicolumn{2}{|c|}{13415} & \multicolumn{2}{|c|}{13415} \\
\hline
\end{tabular}

The exam of the data in tables 6 and 7 shows that any of the coefficients of the e-commerce indicators (B2B, B2C, $\mathrm{B} 2 \mathrm{~B} \& \mathrm{~B} 2 \mathrm{C}$ ), neither in lagged nor in unlagged regressions, is significantly different from zero at the usual significance levels. Therefore, our data suggest that the implementation of e-commerce does not seem to have an influence on the percentual variation of revenues. Then, our data support $\mathrm{H} 1$. This means that a substitution effect may exist between the sales by physical channels and e-commerce sales, or either that most companies are not taking full advantage of the potential of e-commerce.

Regression Results for the Test of H1 (Lagged Regression)

Table 7

\begin{tabular}{|c|c|c|c|c|c|c|}
\hline \multirow[t]{2}{*}{$\begin{array}{l}\text { Dep variable= } \\
\text { VarRevenue }\end{array}$} & \multicolumn{2}{|c|}{ Ecom $=$ B2B } & \multicolumn{2}{|c|}{$E \operatorname{com}=B 2 C$} & \multicolumn{2}{|c|}{ Ecom $=$ B2B\&B2C } \\
\hline & Coef. (std. err.) & t (p-val.) & Coef. (std. err.) & t (p-val.) & Coef. (std. err.) & t (p-val.) \\
\hline Ecom & $-0.693(0.834)$ & $-0.83(0.406)$ & $1.020(1.033)$ & $0.99(0.323)$ & $-0.355(1.050)$ & $-0.34(0.735)$ \\
\hline Age & $0.051(0.026)$ & $1.92(0.055)$ & $0.051(0.026)$ & $1.90(0.058)$ & $0.051(0.026)$ & $1.91(0.056)$ \\
\hline LogRevenue & $-0.713(0.236)$ & $-3.02(0.003)$ & $-0.737(0.234)$ & $-3.14(0.002)$ & $-0.729(0.235)$ & $-3.10(0.002)$ \\
\hline ClConc & $0.045(0.013)$ & $3.53(0.000)$ & $0.047(0.012)$ & $3.69(0.000)$ & $0.046(0.012)$ & $3.59(0.000)$ \\
\hline UCapac & $-0.024(0.029)$ & $-0.81(0.418)$ & $-0.023(0.029)$ & $-0.80(0.426)$ & $-0.023(0.029)$ & $-0.80(0.427)$ \\
\hline Exports & $0.106(0.014)$ & $7.37(0.000)$ & $0.106(0.014)$ & $7.36(0.000)$ & $0.106(0.014)$ & $7.38(0.000)$ \\
\hline $\operatorname{Sec} 01$ & $9.163(1.529)$ & $5.99(0.000)$ & $9.173(1.528)$ & $6.00(0.000)$ & $9.201(1.527)$ & $6.02(0.000)$ \\
\hline $\mathrm{Sec} 02$ & $6.028(1.210)$ & $4.98(0.000)$ & $5.988(1.209)$ & $4.95(0.000)$ & $6.032(1.209)$ & $4.99(0.000)$ \\
\hline $\mathrm{Sec} 03$ & $11.491(4.847)$ & $2.37(0.018)$ & $11.223(4.854)$ & $2.31(0.021)$ & $11.483(4.863)$ & $2.36(0.018)$ \\
\hline $\mathrm{Sec} 04$ & $1.851(1.418)$ & $1.31(0.192)$ & $1.746(1.425)$ & $1.22(0.221)$ & $1.844(1.418)$ & $1.30(0.194)$ \\
\hline $\operatorname{Sec} 05$ & $7.388(1.858)$ & $3.97(0.000)$ & $7.353(1.857)$ & $3.96(0.000)$ & $7.404(1.858)$ & $3.98(0.000)$ \\
\hline $\operatorname{Sec} 06$ & $-1.306(1.829)$ & $-0.71(0.475)$ & $-1.312(1.826)$ & $-0.72(0.472)$ & $-1.287(1.827)$ & $-0.70(0.481)$ \\
\hline $\operatorname{Sec} 07$ & $6.801(1.646)$ & $4.13(0.000)$ & $6.759(1.654)$ & $4.08(0.000)$ & $6.789(1.651)$ & $4.11(0.000)$ \\
\hline $\operatorname{Sec} 08$ & $-0.507(1.366)$ & $-0.37(0.711)$ & $-0.556(1.368)$ & $-0.41(0.684)$ & $-0.501(1.365)$ & $-0.37(0.713)$ \\
\hline $\operatorname{Sec} 09$ & $5.964(1.446)$ & $4.12(0.000)$ & $6.006(1.444)$ & $4.16(0.000)$ & $5.980(1.443)$ & $4.14(0.000)$ \\
\hline $\operatorname{Sec} 10$ & $3.605(1.400)$ & $2.57(0.010)$ & $3.614(1.399)$ & $2.58(0.010)$ & $3.615(1.400)$ & $2.58(0.010)$ \\
\hline Sec11 & $-3.018(1.715)$ & $-1.76(0.079)$ & $-2.952(1.713)$ & $-1.72(0.085)$ & $-2.995(1.714)$ & $-1.75(0.081)$ \\
\hline $\operatorname{Sec} 12$ & $2.858(2.021)$ & $1.41(0.158)$ & $2.935(2.022)$ & $1.45(0.147)$ & $2.895(2.021)$ & $1.43(0.152)$ \\
\hline $\operatorname{Sec} 14$ & $3.630(1.713)$ & $2.12(0.034)$ & $3.586(1.715)$ & $2.09(0.037)$ & $3.628(1.715)$ & $2.11(0.035)$ \\
\hline $\operatorname{Sec} 15$ & $1.099(2.197)$ & $0.50(0.617)$ & $1.082(2.195)$ & $0.49(0.622)$ & $1.114(2.197)$ & $0.51(0.612)$ \\
\hline $\operatorname{Sec} 16$ & $2.452(2.257)$ & $1.09(0.277)$ & $2.359(2.259)$ & $1.04(0.296)$ & $2.426(2.259)$ & $1.07(0.283)$ \\
\hline $\operatorname{Sec} 17$ & $3.213(1.572)$ & $2.04(0.041)$ & $3.225(1.568)$ & $2.06(0.040)$ & $3.229(1.570)$ & $2.06(0.040)$ \\
\hline Sec 18 & $10.902(5.400)$ & $2.02(0.044)$ & $10.951(5.396)$ & $2.03(0.043)$ & $10.923(5.402)$ & $2.02(0.043)$ \\
\hline Sec19 & $-0.541(1.819)$ & $-0.30(0.766)$ & $-0.642(1.814)$ & $-0.35(0.723)$ & $-0.594(1.819)$ & $-0.33(0.744)$ \\
\hline $\operatorname{Sec} 20$ & $-1.182(1.924)$ & $-0.61(0.539)$ & $-1.253(1.922)$ & $-0.65(0.514)$ & $-1.221(1.922)$ & $-0.64(0.525)$ \\
\hline Intercept & $3.299(4.480)$ & $0.74(0.462)$ & $3.467(4.481)$ & $0.77(0.439)$ & $3.434(4.483)$ & $0.77(0.444)$ \\
\hline $\mathrm{F}$ & \multicolumn{2}{|c|}{$9.75(\mathrm{p}<0.001)$} & \multicolumn{2}{|c|}{$9.70(\mathrm{p}<0.001)$} & \multicolumn{2}{|c|}{$9.63(\mathrm{p}<0.001)$} \\
\hline R-squared & \multicolumn{2}{|c|}{0.0193} & \multicolumn{2}{|c|}{0.0194} & \multicolumn{2}{|c|}{0.0193} \\
\hline Clusters & \multicolumn{2}{|c|}{2303} & \multicolumn{2}{|c|}{2303} & \multicolumn{2}{|c|}{2303} \\
\hline $\mathrm{N}$ & \multicolumn{2}{|c|}{10877} & \multicolumn{2}{|c|}{10877} & \multicolumn{2}{|c|}{10877} \\
\hline
\end{tabular}


With regard to the control variables, results indicate that firm size and capacity utilization may have an influence but the direction is not clear, as the sign of their coefficients is not consistent across the regression models. Sectoral ascription may also have an influence, depending on the sector. In addition, our findings evidence that firms with high degrees of client concentration and those which export have also higher revenue increases. Finally, age does not seem to have a significant influence in any of the models.

Tables 8 and 9 show the results of the six regression models estimated to test $\mathrm{H} 2$.

Regression Results for the Test of $\mathbf{H} 2$ (Unlagged Regression)

Table 8

\begin{tabular}{|c|c|c|c|c|c|c|}
\hline \multirow{2}{*}{$\begin{array}{l}\text { Dep variable= } \\
\text { Profitability }\end{array}$} & \multicolumn{2}{|c|}{ Ecom $=$ B2B } & \multicolumn{2}{|c|}{ Ecom $=$ B2C } & \multicolumn{2}{|c|}{ Ecom $=$ B2B\&B2C } \\
\hline & Coef. (std. err.) & t (p-val.) & Coef. (std. err.) & t (p-val.) & Coef. (std. err.) & t (p-val.) \\
\hline Ecom & $0.496(1.229)$ & $0.40(0.686)$ & $0.044(0.874)$ & $0.05(0.960)$ & $2.031(0.822)$ & $2.47(0.014)$ \\
\hline Age & $-0.034(0.030)$ & $-1.10(0.271)$ & $-0.033(0.031)$ & $-1.09(0.276)$ & $-0.034(0.031)$ & $-1.10(0.272)$ \\
\hline LogRevenue & $0.717(1.038)$ & $0.69(0.490)$ & $0.726(1.025)$ & $0.71(0.478)$ & $0.713(1.027)$ & $0.69(0.487)$ \\
\hline ClConc & $0.023(0.032)$ & $0.72(0.470)$ & $0.023(0.032)$ & $0.72(0.471)$ & $0.024(0.032)$ & $0.75(0.454)$ \\
\hline UCapac & $0.085(0.093)$ & $0.91(0.364)$ & $0.084(0.094)$ & $0.90(0.368)$ & $0.085(0.094)$ & $0.90(0.366)$ \\
\hline Exports & $0.011(0.023)$ & $0.50(0.620)$ & $0.011(0.023)$ & $0.49(0.621)$ & $0.011(0.023)$ & $0.49(0.626)$ \\
\hline Sec01 & $-2.963(1.900)$ & $-1.56(0.119)$ & $-2.983(1.918)$ & $-1.55(0.120)$ & $-2.928(1.904)$ & $-1.54(0.124)$ \\
\hline $\mathrm{Sec} 02$ & $-0.345(2.462)$ & $-0.14(0.888)$ & $-0.349(2.471)$ & $-0.14(0.887)$ & $-0.356(2.465)$ & $-0.14(0.885)$ \\
\hline $\mathrm{Sec} 03$ & $10.232(3.143)$ & $3.25(0.001)$ & $10.211(3.185)$ & $3.21(0.001)$ & $10.053(3.156)$ & $3.19(0.001)$ \\
\hline $\mathrm{Sec} 04$ & $-5.424(4.245)$ & $-1.28(0.201)$ & $-5.426(4.258)$ & $-1.27(0.203)$ & $-5.475(4.250)$ & $-1.29(0.198)$ \\
\hline $\operatorname{Sec} 05$ & $-0.027(3.883)$ & $-0.01(0.994)$ & $-0.038(3.908)$ & $-0.01(0.992)$ & $-0.020(3.892)$ & $-0.01(0.996)$ \\
\hline $\operatorname{Sec} 06$ & $-5.686(4.257)$ & $-1.34(0.182)$ & $-5.701(4.278)$ & $-1.33(0.183)$ & $-5.720(4.278)$ & $-1.34(0.181)$ \\
\hline $\operatorname{Sec} 07$ & 2.024 (1.909) & $1.06(0.289)$ & $2.026(1.909)$ & $1.06(0.289)$ & $1.973(1.913)$ & $1.03(0.303)$ \\
\hline $\operatorname{Sec} 08$ & $2.173(3.827)$ & $0.57(0.570)$ & $2.164(3.847)$ & $0.56(0.574)$ & $2.125(3.841)$ & $0.55(0.580)$ \\
\hline $\operatorname{Sec} 09$ & $1.285(2.113)$ & $0.61(0.543)$ & $1.277(2.119)$ & $0.60(0.547)$ & $1.303(2.117)$ & $0.62(0.538)$ \\
\hline $\operatorname{Sec} 10$ & $-0.776(3.080)$ & $-0.25(0.801)$ & $-0.782(3.088)$ & $-0.25(0.800)$ & $-0.773(3.086)$ & $-0.25(0.802)$ \\
\hline Sec11 & $-0.474(4.949)$ & $-0.10(0.924)$ & $-0.483(4.956)$ & $-0.10(0.922)$ & $-0.438(4.953)$ & $-0.09(0.929)$ \\
\hline $\operatorname{Sec} 12$ & $-3.416(2.591)$ & $-1.32(0.187)$ & $-3.435(2.606)$ & $-1.32(0.188)$ & $-3.387(2.603)$ & $-1.30(0.193)$ \\
\hline $\operatorname{Sec} 14$ & $-0.571(2.920)$ & $-0.20(0.845)$ & $-0.578(2.928)$ & $-0.20(0.843)$ & $-0.656(2.940)$ & $-0.22(0.823)$ \\
\hline $\operatorname{Sec} 15$ & $-7.015(4.240)$ & $-1.65(0.098)$ & $-7.026(4.250)$ & $-1.65(0.098)$ & $-7.070(4.253)$ & $-1.66(0.097)$ \\
\hline Sec16 & $-3.848(2.811)$ & $-1.37(0.171)$ & $-3.841(2.802)$ & $-1.37(0.171)$ & $-3.958(2.817)$ & $-1.40(0.160)$ \\
\hline $\operatorname{Sec} 17$ & $-3.739(2.586)$ & $-1.45(0.148)$ & $-3.748(2.594)$ & $-1.44(0.149)$ & $-3.736(2.592)$ & $-1.44(0.150)$ \\
\hline $\operatorname{Sec} 18$ & $-7.910(4.874)$ & $-1.62(0.105)$ & $-7.922(4.884)$ & $-1.62(0.105)$ & $-7.884(4.881)$ & $-1.62(0.106)$ \\
\hline Sec19 & $-6.794(4.565)$ & $-1.49(0.137)$ & $-6.761(4.527)$ & $-1.49(0.135)$ & $-6.782(4.523)$ & $-1.50(0.134)$ \\
\hline $\operatorname{Sec} 20$ & $-2.622(4.657)$ & $-0.56(0.573)$ & $-2.596(4.630)$ & $-0.56(0.575)$ & $-2.585(4.620)$ & $-0.56(0.576)$ \\
\hline Intercept & $-11.419(23.027)$ & $-0.50(0.620)$ & $-11.508(22.894)$ & $-0.50(0.615)$ & $-11.427(22.909)$ & $-0.50(0.618)$ \\
\hline $\mathrm{F}$ & \multicolumn{2}{|c|}{$7.24(\mathrm{p}<0.001)$} & \multicolumn{2}{|c|}{$7.06(\mathrm{p}<0.001)$} & \multicolumn{2}{|c|}{$7.21(\mathrm{p}<0.001)$} \\
\hline R-squared & \multicolumn{2}{|c|}{0.004} & \multicolumn{2}{|c|}{0.004} & \multicolumn{2}{|c|}{0.004} \\
\hline Clusters & \multicolumn{2}{|c|}{2543} & \multicolumn{2}{|c|}{2543} & \multicolumn{2}{|c|}{2543} \\
\hline $\mathrm{N}$ & \multicolumn{2}{|c|}{13416} & \multicolumn{2}{|c|}{13416} & \multicolumn{2}{|c|}{13416} \\
\hline
\end{tabular}

Table 8 contains the results of the unlagged models. The coefficient of B2B\&B2C is positive and significant at the 5 $\%$ level. This finding suggests that companies which jointly adopted B2B and B2C e-commerce have profitability levels higher than those of their non-adopting counterparts. However, results also evidence that neither B2B nor B2C ecommerce alone seem to have a significant effect in the profitability of the year we measure both the e-commerce indicators and the rest of independent variables used as controls. Therefore, we can conclude that a strong commitment, which involves both $\mathrm{B} 2 \mathrm{~B}$ and $\mathrm{B} 2 \mathrm{C}$ ecommerce, is needed to obtain profitability gains in the short term.

Regarding the control variables, none of them is found to be significant in the unlagged regression models, with the exception of some specific sectoral ascriptions.

Table 9

Regression Results for the Test of $\mathbf{H 2}$ (Unlagged Regression)

\begin{tabular}{|c|c|c|c|c|c|c|}
\hline \multirow[t]{2}{*}{$\begin{array}{l}\text { Dep variable= } \\
\text { Profitability }\end{array}$} & \multicolumn{2}{|c|}{$E \operatorname{com}=B 2 B$} & \multicolumn{2}{|c|}{$E \operatorname{com}=B 2 C$} & \multicolumn{2}{|c|}{ Ecom $=$ B2B\&B2C } \\
\hline & Coef. (std. err.) & t (p-val.) & Coef. (std. err.) & t (p-val.) & Coef. (std. err.) & t (p-val.) \\
\hline Ecom & $1.507(0.746)$ & $2.02(0.043)$ & $2.235(0.505)$ & $4.43(0.000)$ & $3.232(0.833)$ & $3.88(0.000)$ \\
\hline$\overline{\text { Age }}$ & $-0.041(0.024)$ & $-1.70(0.089)$ & $-0.041(0.021)$ & $-1.93(0.054)$ & $-0.041(0.024)$ & $-1.69(0.091)$ \\
\hline LogRevenue & $1.170(0.498)$ & $2.35(0.019)$ & $1.195(0.458)$ & $2.61(0.009)$ & $1.189(0.497)$ & $2.39(0.017)$ \\
\hline ClConc & $0.055(0.041)$ & $1.34(0.179)$ & $0.055(0.040)$ & $1.36(0.174)$ & $0.055(0.041)$ & $1.34(0.181)$ \\
\hline UCapac & $-0.015(0.129)$ & $-0.12(0.906)$ & $-0.016(0.129)$ & $-0.13(0.899)$ & $-0.016(0.129)$ & $-0.12(0.901)$ \\
\hline Exports & $0.020(0.015)$ & $1.32(0.186)$ & $0.019(0.012)$ & $1.60(0.111)$ & $0.019(0.015)$ & $1.30(0.195)$ \\
\hline $\operatorname{Sec} 01$ & $-3.242(2.700)$ & $-1.20(0.230)$ & $-3.435(2.714)$ & $-1.27(0.206)$ & $-3.248(2.697)$ & $-1.20(0.229)$ \\
\hline $\mathrm{Sec} 02$ & $-1.218(3.560)$ & $-0.34(0.732)$ & $-1.313(3.614)$ & $-0.36(0.716)$ & $-1.236(3.560)$ & $-0.35(0.728)$ \\
\hline $\operatorname{Sec} 03$ & $9.132(4.244)$ & $2.15(0.032)$ & $8.721(4.001)$ & $2.18(0.029)$ & $8.928(4.234)$ & $2.11(0.035)$ \\
\hline $\mathrm{Sec} 04$ & $-6.082(4.652)$ & $-1.31(0.191)$ & $-6.246(4.625)$ & $-1.35(0.177)$ & $-6.126(4.653)$ & $-1.32(0.188)$ \\
\hline $\operatorname{Sec} 05$ & $-0.583(4.333)$ & $-0.13(0.893)$ & $-0.745(4.433)$ & $-0.17(0.866)$ & $-0.589(4.333)$ & $-0.14(0.892)$ \\
\hline $\operatorname{Sec} 06$ & $-7.564(5.114)$ & $-1.48(0.139)$ & $-7.647(5.136)$ & $-1.49(0.137)$ & $-7.628(5.114)$ & $-1.49(0.136)$ \\
\hline $\operatorname{Sec} 07$ & $1.776(2.841)$ & $0.63(0.532)$ & $1.761(2.838)$ & $0.62(0.535)$ & $1.760(2.841)$ & $0.62(0.536)$ \\
\hline $\operatorname{Sec} 08$ & $1.285(4.871)$ & $0.26(0.792)$ & $1.159(4.917)$ & $0.24(0.814)$ & $1.261(4.871)$ & $0.26(0.796)$ \\
\hline $\operatorname{Sec} 09$ & $0.071(3.349)$ & $0.02(0.983)$ & $0.073(3.387)$ & $0.02(0.983)$ & $0.063(3.348)$ & $0.02(0.985)$ \\
\hline $\operatorname{Sec} 10$ & $-1.284(4.011)$ & $-0.32(0.749)$ & $-1.314(4.095)$ & $-0.32(0.748)$ & $-1.302(4.012)$ & $-0.32(0.745)$ \\
\hline
\end{tabular}




\begin{tabular}{|c|c|c|c|c|c|c|}
\hline $\begin{array}{l}\text { Dep variable= } \\
\text { Profitability }\end{array}$ & Ecom $=$ B2B & Ecom $=\mathbf{B} 2 \mathrm{C}$ & Ecom $=B 2 B \& B 2 C$ & $\begin{array}{l}\text { Dep variable= } \\
\text { Profitability }\end{array}$ & Ecom $=\mathbf{B} 2 \mathrm{~B}$ & Ecom $=B 2 C$ \\
\hline & Coef. (std. err.) & $t$ (p-val.) & Coef. (std. err.) & & Coef. (std. err.) & $t$ (p-val.) \\
\hline Sec11 & $-2.507(6.492)$ & $-0.39(0.699)$ & $-2.499(6.491)$ & $-0.39(0.700)$ & $-2.496(6.493)$ & $-0.38(0.701)$ \\
\hline $\operatorname{Sec} 12$ & $-6.017(4.066)$ & $-1.48(0.139)$ & $-6.044(3.964)$ & $-1.52(0.127)$ & $-6.045(4.064)$ & $-1.49(0.137)$ \\
\hline Sec14 & $-1.911(3.614)$ & $-0.53(0.597)$ & $-1.942(3.657)$ & $-0.53(0.595)$ & $-1.994(3.616)$ & $-0.55(0.581)$ \\
\hline $\operatorname{Sec} 15$ & $-9.541(5.425)$ & $-1.76(0.079)$ & $-9.608(5.072)$ & $-1.89(0.058)$ & $-9.627(5.427)$ & $-1.77(0.076)$ \\
\hline Sec16 & $-5.074(3.583)$ & $-1.42(0.157)$ & $-5.081(3.573)$ & $-1.42(0.155)$ & $-5.151(3.584)$ & $-1.44(0.151)$ \\
\hline Sec17 & $-6.052(4.157)$ & $-1.46(0.146)$ & $-6.100(4.211)$ & $-1.45(0.148)$ & $-6.083(4.155)$ & $-1.46(0.143)$ \\
\hline $\operatorname{Sec} 18$ & $-11.605(6.190)$ & $-1.87(0.061)$ & $-11.613(6.180)$ & $-1.88(0.060)$ & $-11.616(6.192)$ & $-1.88(0.061)$ \\
\hline Sec19 & $-9.425(5.434)$ & $-1.73(0.083)$ & $-9.396(5.270)$ & $-1.78(0.075)$ & $-9.339(5.434)$ & $-1.72(0.086)$ \\
\hline $\operatorname{Sec} 20$ & $-3.834(5.020)$ & $-0.76(0.445)$ & $-3.831(4.810)$ & $-0.80(0.426)$ & $-3.729(5.021)$ & $-0.74(0.458)$ \\
\hline Intercept & $-11.945(17.835)$ & $-0.67(0.503)$ & $-12.221(17.819)$ & $-0.69(0.493)$ & $-12.152(17.831)$ & $-0.68(0.496)$ \\
\hline $\mathrm{F}$ & \multicolumn{2}{|c|}{$7.22(p<0.001)$} & \multicolumn{2}{|c|}{$7.30(p<0.001)$} & \multicolumn{2}{|c|}{$7.43(p<0.001)$} \\
\hline R-squared & \multicolumn{2}{|c|}{0.0042} & \multicolumn{2}{|c|}{0.0042} & \multicolumn{2}{|c|}{0.0042} \\
\hline Clusters & \multicolumn{2}{|c|}{2303} & \multicolumn{2}{|c|}{2303} & \multicolumn{2}{|c|}{2303} \\
\hline $\mathrm{N}$ & \multicolumn{2}{|c|}{10878} & \multicolumn{2}{|c|}{10878} & \multicolumn{2}{|c|}{10878} \\
\hline
\end{tabular}

Results in table 9, which contains the estimations of the lagged models, evidence that in the year following to that of the measurement of the e-commerce status, significant profitability gains are achieved even if we adopt only B2B or $\mathrm{B} 2 \mathrm{C}$ alone. Therefore, our data suggest that the return of partial implementations is positive and significant, but somewhat delayed. Then, we can conclude that $\mathrm{H} 2$ is also supported but with one exception: if the company does not make a strong commitment with e-commerce involving both $\mathrm{B} 2 \mathrm{~B}$ and $\mathrm{B} 2 \mathrm{C}$ options then returns via cost reductions will not be immediately obtained.

With regard to the control variables of the lagged models, only firm size proxied through the natural log of net revenue and certain sectoral ascriptions seem to have a positive effect on the profitability of the subsequent year. The rest of the variables do not exert a significant impact.

\section{Conclusions}

The main goal of this paper is to help reducing a significant gap in the literature by empirically testing the influence of ecommerce implementation on sales growth and profitability.

In spite of the large increase in e-sales, nowadays B2B/B2C e-commerce represents only a small segment of total sales. Not all companies implement e-commerce with the same intensity. For example, some firms implement only B2B e-commerce, others only B2C and others both the B2B and B2C options. So, there are various levels of engagement with e-commerce.

In this research, we used data from the Survey on Business Strategies of the Spanish Ministry of Science and Technology to assess whether the implementation of e-commerce has an effect on revenue growth and profitability. We separately considered $\mathrm{B} 2 \mathrm{~B}$ and $\mathrm{B} 2 \mathrm{C}$ firms, and companies that jointly implemented both versions of e-commerce.

Very little has been written about the impact of the implementation of e-commerce on sales. Results show that none of the three e-commerce possibilities seems to influence on the revenue growth. It does not matter that there is a strengthened commitment to e-commerce implementation. Nevertheless, it could happen that the effects of e-commerce adoption will be in a lagged way. That is why we also studied whether there were changes in the variation of the revenue figure one year after the implementation of e-commerce. With this analysis, we found no evidence that the revenue figures improved compared to those of companies not using e-commerce. These findings suggest that a substitution effect may exist between the sales by physical channels and e- commerce sales, or either that most companies are not taking full advantage of the potential of e-commerce.

Regarding the effects on profitability, the results obtained show that companies that have a firm commitment with ecommerce obtain better performance versus those that implement only the $\mathrm{B} 2 \mathrm{~B}$ or only the $\mathrm{B} 2 \mathrm{C}$ option. Companies using both $\mathrm{B} 2 \mathrm{~B}$ and $\mathrm{B} 2 \mathrm{C}$ commerce in e-sales find their profitability levels increased with respect to those of nonadopting companies in the year of the implementation. However, B2B or B2C e-commerce alone are not enough to obtain immediate returns via cost reductions. In such cases, profitability gains are evidenced only when we used a lagged version of the proxy used, that is, when we consider as dependent variable in the models the profitability of the year subsequent to that of the measurement of the independent variables. One possible explanation for this finding may be that when companies implement only B2B or B2C e-commerce, at first there is a lack of consumer confidence. However, consumers are more trusting in the case of companies more committed to e-commerce (B2B \& B2C). In any case, the lack of trust disappears as time goes by.

The findings obtained allow us to affirm that neither B2B nor B2C e-commerce seem to influence on the revenue growth. The paper makes a further interesting and important contribution: companies which use both the B2B and the $\mathrm{B} 2 \mathrm{C}$ option find immediately increased their profitability levels with respect to those of non-adopting companies.

As limitations of the paper, it should be noted that the implementation of $\mathrm{B} 2 \mathrm{~B}$ sales is typically linked to the implementation of e-procurement. Therefore, improvements in profitability could be caused by either one or both innovations. It is also necessary to take into account that the success of ecommerce is conditioned by customer satisfaction, which in turn depends on system quality (website design and interactivity), information quality (informativeness and security), and service quality (responsiveness and trust (Lin, 2010). Finally, as future research lines we can mention the study of the effect of the number of years of experience with ecommerce on revenue growth and profitability, as experienced companies may have a better understanding of the possibilities that this innovation offers for increasing company revenue and returns. Other factors that may have an impact on the success of e-commerce in terms of revenue and profitability are the quality of the web application that the company uses for ecommerce and the security issues. It would also be interesting the extension of the study to other sectors. Finally, it could be of interest the study of the effect of e-commerce on the 
number of physical units sold, as one of the feasible effects of the introduction of e-commerce is that the company may sell

\section{Acknowledgment}

This work has been partially funded by the Spanish Ministry of Economy and Competitiveness (Grant ECO2014-52519-R) and by the Spanish Department of Science, Innovation and Universities (Project RTI2018-099235-B-I00).

\section{References}

Argote, L. (1999). Organizational Learning: Creating, Retaining and Transferring Knowledge. Norwell, Massachusetts: Kluwer Academic Publishers.

Autio, E., Sapienza, H. J., \& Almeida, J. G. (2000). Effects of Age at Entry, Knowledge Intensity, and Imitability on International Growth. Academy of Management Journal, 43(5), 909-924. https://doi.org/10.2307/1556419

Bakos, Y. (2001). The emerging landscape for retail e-commerce. Journal of Economic Perspectives, 15(1), 69-80. https://doi.org/10.1257/jep.15.1.69

Barsauskas, P., Sarapovas, T., \& Cvilikas, A. (2008). The evaluation of e-commerce impact on business efficiency. Baltic Journal of Management, 3(1), 71-91. https://doi.org/10.1108/17465260810844275

Baumol, W. J. (1967). Macroeconomics of unbalanced growth: The anatomy of an urban crisis. American Economic Review, 57, 415-426.

Beck, T., Demirguc-Kunt, A., \& Maksimovic, V. (2005). Financial and Legal Constraints to Growth: Does Firm Size Matter? The Journal of Finance, 60(1), 137-177. https://doi.org/10.1111/j.1540-6261.2005.00727.x

Bergendahl, G. (2005). Models for investment in electronic commerce-financial perspectives with empirical evidence. Omega, The International Journal of Management Science, 33, 363-376. https://doi.org/10.1016/j.omega. 2004.07.021

Bolumole, Y. A. (2001). The supply chain role of third-party logistics providers. The International Journal of Logistics Management, 12(2), 87-102. https://doi.org/10.1108/09574090110806316

Braojos, J., Benitez, J., \& Llorens, J. (2015). How do small firms learn to develop a social media competence? International Journal of Information Management, 35(4), 443-458. https://doi.org/10.1016/j.ijinfomgt.2015.04.003

Cao, L., Li, L. (2015). The Impact of Cross-Channel Integration on Retailers' Sales Growth. Journal of Retailing 91 (2), pp. 198-216. https://doi.org/10.1016/j.jretai.2014.12.005

CNMC (Comision Nacional de los Mercados y la Competencia) (2017). E-commerce Report. CNMC. Available from internet: https://telecos.cnmc.es/informes-comercio-electronico.

Coad, A., Segarra, A., \& Teruel, M. (2016). Innovation and firm growth: Does firm age play a role? Research Policy, 45, 387-400. https://doi.org/10.1016/j.respol.2015.10.015

Coviello, N. E., \& Brodie, R. J. (2001) Contemporary marketing practices of consumer and business-to-business firms: How different are they?. Journal of Business and Industrial Marketing, 16(5), 382-400. https://doi.org/10.1108/ 08858620110400223

Dant, R. P., \& Brown, J. R. (2008). Bridging the B2C and B2B Research Divide: The Domain of Retailing Literature. Journal of Retailing, 84(4), 371-397. https://doi.org/10.1016/j.jretai.2008.09.005

Davidaviciene, V., Pabedinskaite, A., \& Davidavicius, S. (2017). Social networks in B2B and B2C communication. Transformations in Business \& Economics, 16(1), 69-84.

Dębkowska, K. (2017). E-services in business models of enterprises in the logistics sector. Business: Theory and Practice, 18(1), 79-87. https://doi.org/10.3846/btp.2017.009

Dogan, M. (2013). Does Firm Size Affect The Firm Profitability? Evidence from Turkey. Research Journal of Finance and Accounting, 4(4), 53-59.

Duch-Brown, N., Grzybowski, L., Romahn, A., \& Verboven, F. (2017). The impact of online sales on consumers and firms. Evidence from consumer electronics. International Journal of Industrial Organization, 52, 30-62. https://doi.org/10.1016/j.ijindorg.2017.01.009

Eurostat (2019). Digital economy and society. Available from internet: https://appsso.eurostat.ec.europa.eu/nui/show.do? dataset $=$ isoc_ec_eseln2\&lang=en

Falk, M., \& Hagsten, E. (2015). E-commerce trends and impacts across Europe. International Journal of Production Economics, 170, 357-369. https://doi.org/10.1016/j.ijpe.2015.10.003

Filatotchev, I., \& Piesse, J. (2009). R\&D, internationalization and growth of newly listed firms: European evidence. Journal of International Business Studies, 40(8), 1260-1276. https://doi.org/10.1057/jibs.2009.18 
Goddard, J., Tavakoli, M., \& Wilson, J. O. S. (2005). Determinants of profitability in European manufacturing and services: evidence from a dynamic panel model. Applied Financial Economics, 15, $1269-1282$. https://doi.org/10.1080/09603100500387139

Gunasekaran, A., Marri, H., McGaughey, R., \& Nebhwani, M. (2002). E-commerce and its impact on operations management. International Journal of Production Economics, 75, 185-197. https://doi.org/10.1016/S0925-5273(01) 00191-8

Hall, M., \& Weiss, L. (1967). Firm Size and Profitability. The Review of Economics and Statistics, 49(3), 319-331. https://doi.org/10.2307/1926642

Hosseini, M., Brege, S., \& Nord, T. (2018). A combined focused industry and company size investigation of the internationalization-performance relationship: The case of small and medium-sized enterprises (SMEs) within the Swedish wood manufacturing industry. Forest Policy and Economics, 97, 110-121. https://doi.org/10.1016/j.forpol. 2018.09.013

Iankova, S., Davies, I., Archer-Brown, C., Marder, B., \& Yau, A. (2018). A comparison of social media marketing between B2B, B2C and mixed business models. Industrial Marketing Management, in press. https://doi.org/10.1016 /j.indmarman.2018.01.001

INE (Instituto Nacional de Estadistica) (2017). Survey on the use of Information and Communication Technologies (ICT) and electronic commerce in companies. INE. Available from internet: https:/www.ine.es/dyngs/INEbase/es/ operacion.htm?c=Estadistica_C\&cid=1254736176743\&menu=ultiDatos\&idp $=1254735576692$

INSEE (Institut National de la Statistique et des Etudes Economiques) (2014). Les TIC et le commerce electronique en 2013. INSEE. Available from internet: https://www.insee.fr/fr/statistiques/2016275? sommaire=2016376.

Jan, P. (2012). Security and Trustworthiness as Drivers of E-shop Competitiveness (Opinions of Young Customers). Journal of Competitiveness, 4(1), 83-98. https://doi.org/10.7441/joc.2012.01.07

Jelassi, T., \& Leenen, S. (2003). An E-Commerce Sales Model for Manufacturing Companies: A Conceptual Framework and a European Example. European Management Journal, 21(1), 38-47. https://doi.org/10.1016/S0263-2373(02) $00151-2$

Kramolis, J., \& Kotaskova, A. (2018). The Gap of Importance of Design in Business between 2014 and 2016. E\&M Economics and Management, 21(2), 133-146. https://doi.org/10.15240/tul/001/2018-2-009

Kvainauskaite, V., Sarapovas, T., \& Cvilikas, A. (2005). Selection and Assessment of E-commerce Models in SMEs. Inzinerine Ekonomika-Engineering Economics, 44(4), 64-70.

Lee, J. (2009). Does Size Matter in Firm Performance? Evidence from US Public Firms. International Journal of the Economics of Business, 16(2), pp. 189-203. https://doi.org/10.1080/13571510902917400

Levitt, B., \& March, J. (1988). Organizational learning. Annual Review of Sociology, 14, 319-340. https://doi.org/10.1146/ annurev.so.14.080188.001535

Lilien, G. L. (2016). The B2B Knowledge Gap. International Journal of Research in Marketing, 33, 543-556. https://doi.org/10.1016/j.ijresmar.2016.01.003

Lin, H. F. (2010). The impact of website Quality Dimensions on Customers Satisfaction in the B2C E-commerce Context. Total Quality Management \& Business Excellence, 18(4), 363-378. https://doi.org/10.1080/14783360701231302

Lorca, P., De Andres, J., \& Garcia-Diez, J. (2017). Factors Affecting the Adoption of B2C by Manufacturing Companies. ICIW 2017, The Twelfth International Conference on Internet and Web Applications and Services, IARIA, June 25 to June 29, Venice (Italy), pp. 52-57.

Lu, J. W., \& Beamish, P. W. (2006). SME internationalization and performance: Growth vs. profitability. Journal of International Entrepreneurship, 4(1), 27-48. https://doi.org/10.1007/s10843-006-8000-7

Michal, P. (2012). On-line Shopping on B2C Markets in the Czech Republic. Journal of Competitiveness, 4(4), 36-49. https://doi.org/10.7441/joc.2012.04.03

Namyslowska, M. (2013). To B2C or Not to B2C. Some Reflections on the Regulation of Unfair Commercial Practices from a Polish Perspective. Journal of Consumer Policy, 36(3), 329-342. https://doi.org/10.1007/s10603-013-9229$\mathrm{x}$

Notta, U., Vlachvei, A., \& Samathrakis, V. (2010). Competitiveness-the case of Greek food manufacturing firms. International Journal of Arts and Sciences, 37, 211-225.

Ozgulbas, N., Koyuncugil, A. S., \& Yilmaz, F. (2006). Identifying the Effect of Firm Size on Financial Performance of SMEs. The Business Review, Cambridge, 6(1), p. 162-167.

Patatoukas, P. N. (2012). Customer-Base Concentration: Implications for Firm Performance and Capital Markets. The Accounting Review, 87(2), 363-392. https://doi.org/10.2308/accr-10198 
Pedro Lorca, Javier de Andres, Julita Garcia-Diez. Impact of E-Commerce Sales on Profitability and Revenue. The Case...

Reijnders, L., \& Hoogeveen, M. J. (2001). Energy effects associated with e-commerce: A case-study concerning online sales of personal computers in The Netherlands. Journal of Environmental Management, 62, 317-321. https://doi.org/10.1006/jema.2001.0440

Sarapovas, T., \& Cvilikas, A. (2006). The Problems of identifying the Essential Business-to-Business E-Commerce Environment Components. Inzinerine Ekonomika-Engineering Economics, 46(1), 74-82.

Solow, R. (1987). We'd better watch out. New York Times Book Review, July 12, p. 36.

Steffens, P., Davidsson, P., \& Fitzsimmons, J. (2009). Performance configurations over time: Implications for growthand profit-oriented strategies. Entrepreneurship Theory and Practice, 33(1), 125-148. https://doi.org/10.1111/j.1540-6520.2008.00283.x

Svatosova, V. (2013). Motivation of Online Buyer Behavior. Journal of Competitiveness, 5(3), 14-30. https://doi.org/10.7441/joc.2013.03.02

Teo, T., \& Bhattacherjee, A. (2014). Knowledge transfer and utilization in IT outsourcing partnerships: a preliminary model of antecedents and outcomes. Information Management, 51(2), 177-186. https://doi.org/10.1016/j.im. 2013.12.001

Tripsas, M., \& Gavetti, G. (2000). Capabilities, cognition, and inertia: evidence from digital imaging. Strategic Management Journal, 21(10/11), 1147-1161. https://doi.org/10.1002/1097-0266(200010/11)21:10/11<1147::AID$\mathrm{SMJ} 128>3.0 . \mathrm{CO} ; 2-\mathrm{R}$

Voulgaris, F., \& Lemonakis, Ch. (2014). Competitiveness and profitability: The case of chemicals, pharmaceuticals and plastics. The Journal of Economic Asymmetries, 11, 46-57. https://doi.org/10.1016/j.jeca.2014.04.003

Willis, J. L. (2004). What impact will E-commerce have on the U.S. economy? Economic Review, Federal Reserve Bank of Kansas City, issue Q II, 53-71.

Zhang, D., Sikveland, M., \& Hermansen, O. (2018). Fishing fleet capacity and profitability. Marine Policy, 88, 116-121. https://doi.org/10.1016/j.marpol.2017.11.017

Ziaullah, M., Yi, F., Akhter, S. N., \& Khan, M. (2014). An Empirical Study on Exploring Relationship among Information Quality, E-satisfaction, E-trust and Young Generation's Commitment to Chinese Online Retailing. South African Journal of Competitiveness, 6(4), 3-18. https://doi.org/10.7441/joc.2014.04.01

The article has been reviewed. Received in July 2018; accepted in November 2019. 